\title{
MOTIVASI DAN HARAPAN MAHASISWA DIFABLE TERHADAP PENDIDIKAN INKLUSI DI UIN SUNAN KALIJAGA
}

\author{
Muryanti dan Tri Mulyani \\ Prodi Sosiologi, Fakultas IImu Sosial dan Humaniora, UIN Sunan Kalijaga \\ e-mail : newsyant@yahoo.com
}

\begin{abstract}
Abstrak
Pendidikan inklusi memberikan harapan bagi kelompok difable untuk mendapatkan pendidikan yang sama dengan warga negara lain. Dengan bekal pendidikan tersebut diharapkan mereka mendapatkan kesempatan yang sama dalam memperoleh pekerjaan demi kesejahteraan untuk kelangsungan hidupnya. Tulisan ini hendak mengkaji bagaimana motivasi dan harapan yang dimiliki oleh para difable terhadap pendidikan inklusi yang diselenggarakan oleh UIN Sunan Kalijaga. Metode penelitian kualitatif dengan penggalian data primer melalui observasi dan wawancara mendalam terhadap mahasiswa difable. Data sekunder diperoleh dari beberapa dokumen yang dimiliki oleh PLD UIN dalam proses penyelenggaraan pendidikan inklusi tersebut. Hasil penelitian menunjukan bahwa motivasi difabel, mayoritas sama dengan mahasiswa lain untuk mendapatkan pendidikan dan mencapai cita-cita sama dengan mahasiswa normal. Proses pembelajaran di UIN belum sesuai dengan keinginan mereka karena banyak kekurangan dari sarana dan prasarana, pendamping mahasiswa difabel dan dosen yang kurang memiliki pengetahuan dan keterampilan untuk mendidik kelompok difabel.
\end{abstract}

Kata Kunci: Pendidikan inklusi, mahasiswa difable, motivasi dan harapan.

Abstract

Inclusion education gives an expectation to group of disabled people to get an equal education as the non-disabled people do. With this education, it is expected that they get the same opportunity to get jobs in order to become more prosper. This writing investigates how the motivation and the expectation of disabled people towards inclusion education which is held by UIN Sunan Kalijaga. The method used is qualitative and the primary data is obtained through observation and interview with disabled students. The secondary data is obtained from some documents owned by PLD UIN which is used to run this inclusion education. The result of investigation shows that most of disabled students have the same motivation as the non-disabled students to get education and pursue their dream. The learning process in UIN itself has not met their expectation because the lack of facilities and assistant, and lecturer who have not possessed proper skills and knowledge to teach disabled students.

Keywords: Inclusion education, disabled students, motivation and expectation. 


\section{Pendahuluan}

Pendidikan inklusif merupakan cita-cita dan harapan tertinggi dari proses pembelajaran yang diselenggarakan oleh sebuah perguruan tinggi. Hal tersebut sesuai dengan amanah dari UUD 1945 pasal 31 (1), (Ilahi, 2013: hlm.24-25) bahwa setiap warga negara berhak mendapatkan pendidikan. Mengingat pendidikan inklusi adalah sebuah konsep pendidikan yang merepresentasikan keseluruhan aspek yang berkaitan dengan keterbukaan dalam menerima anak berkebutuhan khusus untuk memperoleh hak dasarnya (pendidikan) sebagai warga negara. Pendidikan inklusi bertujuan untuk memberikan akses terhadap pendidikan yang sesuai, relevan, terjangkau dan efektif di lingkungan tempat tinggalnya. Aspek pendidikan inklusi adalah kesetaraan kesempatan bagi anak, berdasarkan kebutuhan anak dan demokrasi kemanusiaan. (Kristiyanti,JP65 : hlm 65)

Prosesnya selama ini untuk menyelenggarakan pendidikan inklusi tidak mudah. Hal tersebut dianalisis oleh N. Praptiningrum (2010), yang menyatakan bahwa proses pendidikan inklusi memiliki beberapa kendala. Kendala-kendala tersebut diantaranya: siswa yang berkebutuhan khusus yang diterima belum sesuai dengan kebijakan, terutama tingkat kecerdasan yang berada dibawah rata-rata, tenaga pendidik belum memiliki pemahaman, pengalaman dan kemampuan yang memadai untuk membimbing anak yang memiliki kebutuhan khusus tersebut, dukungan orang tua dan masyarakat masih hanya sebatas moral, belum material dan tenaga untuk membantu anak berkebutuhan khusus dalam proses belajar mengajar. Perlu dukungan semua pihak untuk menyelenggarakan pendidikan inklusif.

Joni Yulianto (2014) dalam tulisannya tentang Konsepsi Difabilitas dan Pendidikan Inklusi menambahkan bahwa implementasi pendidikan inklusi belum sesuai yang diharapkan karena banyaknya kendala dalam mewujudkannya. Beberapa kendala dalam pelaksanaan pendidikan inklusi, diantaranya: (I) kapasitas personal, terkait dengan kesiapan sekolah atau pendidikan tinggi dalam menyelenggarakan pendidikan inklusi.; (2) kesiapan dan keberpihakan institusional, hal ini berkaitan dengan kesiapan manajemen dan lingkungan sekolah.; (3). supporting system, terkait 
dengan peran pemerintah dalam mendukung regulasi tentang pendidikan inklusi dan (4) peran masyarakat dan organisasi non pemerintah, stakeholder tersebut berperan dalam memberikan kesadaran bagi keluarga dan masyarakat akan pentingnya pendidikan inklusi bagi anak difable. (Yulianto, 2014, hlm 1)

Dalam kajian lain, Jamil $S$ (2016) mengkaji tentang Persepsi Siswa Difabel terhadap Praktik Pendidikan Inklusif di SMA Inklusi di Yogyakarta. Jamil menjelaskan bahwa siswa difabel berpendapat bahwa mudahnya akses terhadap materi-materi dengan berbagai variasi sumber pembelajaran, penyampaian guru dengan berbagai macam metode pembelajaran dan sistem yang mendukung pembelajaran inklusif akan menjadikan proses pendidikan inklusif lebih bermakna (Jamil, 2016: hlm 1). Abdullah Fikri (2014) menambahkan tentang Partisipasi Masyarakat Difabel dalam Pembentukan Kebijakan Pendidikan Tinggi. Menurutnya masyarakat difabel maupun civitas akademik masih rendah kontribusinya dalam menelurkan kebijakan tentang penyelenggaraan pendidikan inklusi. Hal tersebut dapat dilihat dari rendahnya tingkat inklusifitas kebijakan pemerintah dalam hal penyelenggaraan. Hal ini menyebabkan perlunya rekonstruksi pendidikan sehingga pendidikan untuk semua dapat diterapkan. (Fikri, 2014: hIm. 20)

Berdasarkan beberapa tulisan tentang penyelenggaraan pendidikan inklusi tersebut dapat dibuat alurnya sebagai berikut:

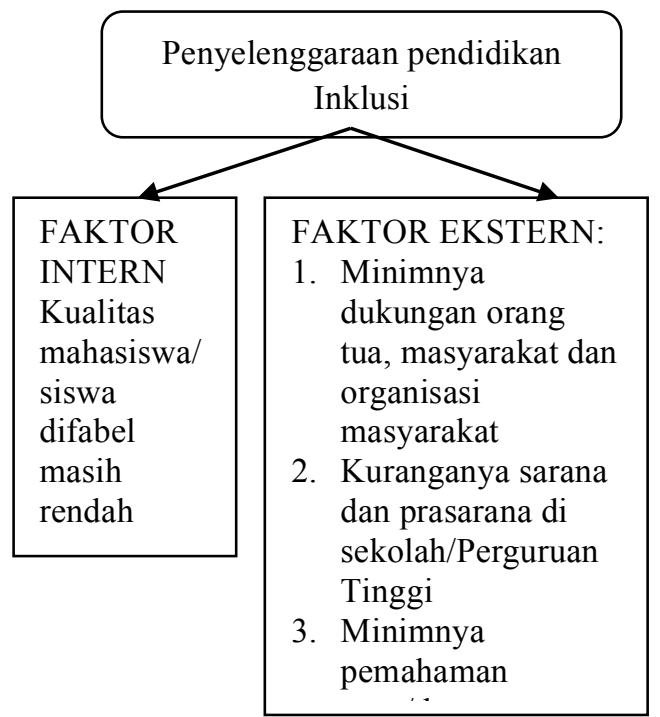

\section{Gambar 1. Alur Penyelenggaraan} Pendidikan Inklusi

Konsep dan alur penelitian tentang pendidikan inklusi tersebut mendasari penelitian ini, yang mengkaji apakah motivasi dan harapan mahasiswa difabel terhadap proses penyelenggaraan pendidikan inklusi yang diselenggarakan oleh UIN Sunan Kalijaga sebagai salah satu Perguruan Tinggi Inklusi di Indonesia. 


\section{Metode}

Analisis menggunakan teori Pendidikan Kritis dan Struktural Fungsional dari Talcot Parson. Penelitian yang dilakukan adalah penelitian kualitatif yang bertujuan untuk menggali informasi secara mendalam. Penggalian data dilakukan dengan: (1) observasi, observasi dilakukan dengan mengamati mahasiswa difable selama berada di kampus, baik dalam proses pembelajaran atau pun tidak dalam proses belajar mengajar. Data yang diperoleh dari observasi terkait dengan kebiasaan mereka, sehingga mengetahui motivasi dan harapannnya secara sungguhsungguh; (2) wawancara, wawancara dilakukan terhadap 10 orang mahasiwa difabel yang tersebar di beberapa fakultas di UIN Sunan Kalijaga. Penelitian tentang bagaimana motivasi dan harapan mahasiswa difabel dalam penyelenggaraan pendidikan inklusi di UIN Sunan Kalijaga perlu dilakukan untuk mengetahui sejauh mana proses pendidikan inklusi diselenggarakan di lingkup UIN Sunan Kalijaga sesuai dengan harapan yang diinginkan oleh mahasiswa difable tersebut. Universitas Islam Negeri (UIN) Sunan Kalijaga merupakan salah satu
Perguruan Tinggi di Yogyakarta. Sebagai salah satu lembaga pendidikan, UIN Sunan Kalijaga memiliki daya tarik tersendiri sehingga setiap tahunnya selalu banyak calon pendaftar yang ingin menimba Ilmu. Menurut data kesekertariatan Pengenalan Budaya Akademik dan kemahasiswaan, tahun 2017 ini, tercatat sebanyak 3662 mahasiswa baru di seluruh Fakultas yang menjadi mahasiswa baru. Jumlah ini menunjukan adanya peningkatan kuota bagi mahasiswa baru, apalagi dibanding tahun sebelumnya yang hanya berjumlah sekitar 3200-an mahasiswa baru.

Sejarahnya, UIN mengalami pergantian dari IAIN (Institute Agama Islam Negeri) menjadi UIN dengan terbitnya Keputusan Presiden RI Nomor 50 Tahun 2004. Dengan proses yang sangat panjang seperti mengajukan Naskah Akademik Proposal Konversi IAIN Sunan Kalijaga, dasar pemikiran, visi, misi, tujuan, dan urgensi perubahan IAIN ke UIN, serta naskah-naskah administrasi termasuk Executive Summary prodi-prodi baru yang akan dibuka. (Pedoman Mahasiswa UIN, 2016). Sebagai Perguruan Tinggi, UIN Sunan Kalijaga merupakan kampus yang terhitung sebagai kampus Inklusi. Tidak hanya 
mahasiswa biasa yang diperbolehkan menjadi bagian dari kampus. Namun, beberapa mahasiswa difable juga diberikan akses dan kesempatan yang sama untuk menimba IImu menjadi mahasiswa. Keterangan dari salah satu mahasiswa baru difable Fakultas IImu Sosial dan Humaniora (FISHUM) Prodi Psikologi tercatat tahun ini ada 10 mahasiswa difable baik tunarungu, tunawicara, tunadaksan, serta tunanetra yang resmi menjadi mahasiswa FISHUM.

Mahasiswa difable ialah mahasiswa dengan kebutuhan khusus. Kata Difable sendiri merupakan singakatan dari "Differently Abled" yang berarti perbedaan kemampuan. Istilah ini juga dicetuskan oleh beberapa NGO di Indonesia untuk mengganti istilah "penyandang cacat" dengan istilah "Penyandang Disabilitas". Sehingga dari sini kita bisa menyimpulkan bahwa mahasiswa difable merupakan mahasiswa dengan kebutuhan khusus. Jumlah mahasiswa difabel di UIN Sunan Kalijaga di semua Fakultas tercatat 71 orang terdiri dari difabel netra, difabel rungu, difabel daksa, autis, sensori, cerebral palsy, slow learner serta skoliostik. Adapun jumlah difabel di Fakultas Dakwah sebanyak 20 orang. Fakultas Ushuluddin 3 orang. Fakultas Sains dan Teknologi 3 orang, Fakultas Tarbiyah dan Keguruan 16 orang. Fakultas Syari'ah dan Hukum ada 4 orang. Fakultas IImu Sosial dan Humaniora ada 8 orang. Fakultas Ekonomi dan Bisnis Islam ada 3 orang. Fakultas Adab dan Ilmu Budaya ada 10 orang. Pascasarjana ada 4 orang. (PLD UIN Suka, 2016).

Berdasarkan hasil wawancara dengan 10 orang informan yang tersebar di beberapa fakultas, motivasi dan harapan mahasiswa dalam proses penyelenggaraan pendidikan inklusi di UIN Sunan Kalijaga adalah sebagai berikut:

Tabel 1. Motivasi dan Harapan Mahasiswa Difabel

\begin{tabular}{|c|c|c|c|c|}
\hline No & $\begin{array}{l}\text { Infor } \\
\text { man } \\
\text { ISe } \\
\text { mes } \\
\text { ter }\end{array}$ & $\begin{array}{l}\text { Disa } \\
\text { bilit } \\
\text { as }\end{array}$ & $\begin{array}{l}\text { Motiva } \\
\text { si }\end{array}$ & $\begin{array}{l}\text { Harap } \\
\text { an }\end{array}$ \\
\hline 1 & $\begin{array}{l}\text { AY } \\
\text { (Se } \\
\text { mes } \\
\text { eter } \\
\text { I) }\end{array}$ & $\begin{array}{l}\text { Disa } \\
\text { bel } \\
\text { Run } \\
\text { gu } \\
\text { dan } \\
\text { Wica } \\
\text { ra }\end{array}$ & $\begin{array}{l}\text { Minat } \\
\text { mendal } \\
\text { ami } \\
\text { Ilmu } \\
\text { Komuni } \\
\text { kasi } \\
\text { dan } \\
\text { menjadi } \\
\text { mahasi } \\
\text { swa }\end{array}$ & $\begin{array}{l}\text { Perba } \\
\text { iki } \\
\text { Insfra } \\
\text { strukt } \\
\text { ur, } \\
\text { ingin } \\
\text { ada } \\
\text { penda } \\
\text { mping } \\
\text { saat } \\
\text { perkul } \\
\text { iahan } \\
\text { berlan } \\
\text { gsung } \\
\text { dan } \\
\text { ingin } \\
\text { memp } \\
\text { erdala } \\
\text { m } \\
\text { bahas }\end{array}$ \\
\hline
\end{tabular}




\begin{tabular}{|c|c|c|c|c|}
\hline & & & & $\begin{array}{l}\text { a } \\
\text { Arab. }\end{array}$ \\
\hline 2 & $\begin{array}{l}\mathrm{N} \\
(\mathrm{Se} \\
\text { mes } \\
\text { eter } \\
\text { l) }\end{array}$ & $\begin{array}{l}\text { Disa } \\
\text { bel } \\
\text { Run } \\
\text { gu } \\
\text { dan } \\
\text { Wica } \\
\text { ra }\end{array}$ & $\begin{array}{l}\text { Dukung } \\
\text { an } \\
\text { orang } \\
\text { tua }\end{array}$ & $\begin{array}{l}\text { Ingin } \\
\text { ada } \\
\text { penda } \\
\text { mping } \\
\text { saat } \\
\text { perkul } \\
\text { iahan } \\
\text { untuk } \\
\text { memp } \\
\text { ermud } \\
\text { ah } \\
\text { mema } \\
\text { hami } \\
\text { apa } \\
\text { yang } \\
\text { dijelas } \\
\text { kan } \\
\text { oleh } \\
\text { dosen }\end{array}$ \\
\hline 3 & $\begin{array}{l}\text { B } \\
\text { (Se } \\
\text { mes } \\
\text { eter } \\
\text { l) }\end{array}$ & $\begin{array}{l}\text { Disa } \\
\text { bel } \\
\text { Run } \\
\text { gu } \\
\text { dan } \\
\text { Wica } \\
\text { ra }\end{array}$ & $\begin{array}{l}\text { Ingin } \\
\text { memba } \\
\text { hagiaka } \\
\mathrm{n} \text { orang } \\
\text { tua dan } \\
\text { menjadi } \\
\text { bagian } \\
\text { dari } \\
\text { kaum } \\
\text { intelekt } \\
\text { ual }\end{array}$ & $\begin{array}{l}\text { Difasil } \\
\text { itasi } \\
\text { penda } \\
\text { mping } \\
\text { saat } \\
\text { perkul } \\
\text { iahan. }\end{array}$ \\
\hline 4 & $\begin{array}{l}\text { A } \\
\text { (Se } \\
\text { mest } \\
\text { er } \\
\text { III) }\end{array}$ & $\begin{array}{l}\text { cere } \\
\text { bral } \\
\text { pals } \\
y\end{array}$ & $\begin{array}{l}\text { Ingin } \\
\text { menge } \\
\text { mbang } \\
\text { kan } \\
\text { keilmua } \\
\mathrm{n} \text { dan } \\
\text { belajar } \\
\text { seperti } \\
\text { orang } \\
\text { lain }\end{array}$ & $\begin{array}{l}\text { Bisa } \\
\text { meng } \\
\text { akses } \\
\text { semu } \\
\text { a } \\
\text { ruang } \\
\text { an } \\
\text { terma } \\
\text { suk } \\
\text { lantai } \\
\text { tiga. }\end{array}$ \\
\hline 5 & $\begin{array}{l}\mathrm{D} \\
\text { (Se } \\
\text { mes } \\
\text { eter } \\
\text { II) }\end{array}$ & $\begin{array}{l}\text { Disa } \\
\text { bel } \\
\text { Run } \\
\text { gu }\end{array}$ & $\begin{array}{l}\text { Ingin } \\
\text { menge } \\
\text { mbang } \\
\text { kan } \\
\text { keilmua } \\
\mathrm{n} \text { dan } \\
\text { belajar } \\
\text { seperti }\end{array}$ & $\begin{array}{l}\text { Difasil } \\
\text { itasi } \\
\text { penda } \\
\text { mping } \\
\text { saat } \\
\text { perkul } \\
\text { iahan. } \\
\text { Apabil }\end{array}$ \\
\hline
\end{tabular}

\begin{tabular}{|c|c|c|c|c|}
\hline & & & $\begin{array}{l}\text { orang } \\
\text { lain }\end{array}$ & $\begin{array}{l}\text { a } \\
\text { tidak } \\
\text { ada } \\
\text { penda } \\
\text { mping } \\
\text { harap } \\
\text { annya } \\
\text { bisa } \\
\text { dibant } \\
\text { u oleh } \\
\text { teman } \\
\text { kelas. }\end{array}$ \\
\hline 6 & $\begin{array}{l}\mathrm{K} \\
\text { (Se } \\
\text { mest } \\
\text { er } \\
\text { III) }\end{array}$ & $\begin{array}{l}\text { Disa } \\
\text { bel } \\
\text { Dak } \\
\text { sa }\end{array}$ & $\begin{array}{l}\text { Supaya } \\
\text { bisa } \\
\text { menjela } \\
\text { jah } \\
\text { dunia }\end{array}$ & $\begin{array}{l}\text { Kuliah } \\
\text { lancar } \\
\text {, ilmu } \\
\text { agam } \\
\text { a } \\
\text { berta } \\
\text { mbah, } \\
\text { mend } \\
\text { apatk } \\
\text { an } \\
\text { penge } \\
\text { tahua } \\
\mathrm{n} \\
\text { secar } \\
\text { a } \\
\text { integr } \\
\text { asi } \\
\text { dan } \\
\text { interk } \\
\text { oneks } \\
\mathrm{i} \\
\text { sebag } \\
\text { ai } \\
\text { bekal } \\
\text { untuk } \\
\text { menje } \\
\text { lajah } \\
\text { dunia }\end{array}$ \\
\hline 7 & $\begin{array}{l}\mathrm{L} \\
\text { (Se } \\
\text { mest } \\
\text { er } \\
\text { VII) }\end{array}$ & $\begin{array}{l}\text { Disa } \\
\text { bel } \\
\text { Dak } \\
\text { sa }\end{array}$ & $\begin{array}{l}\text { Menda } \\
\text { patkan } \\
\text { pendidi } \\
\text { kan } \\
\text { tinggi }\end{array}$ & $\begin{array}{l}\text { Bisa } \\
\text { dapat } \\
\text { kuliah } \\
\text { di } \\
\text { tempa } \\
\text { t yang } \\
\text { memil } \\
\text { iki } \\
\text { akses } \\
\text { bagi } \\
\text { difabe }\end{array}$ \\
\hline
\end{tabular}




\begin{tabular}{|c|c|c|c|c|}
\hline & & & & I \\
\hline 8 & $\begin{array}{l}\text { AS( } \\
\text { Sem } \\
\text { ester } \\
\text { 9) }\end{array}$ & $\begin{array}{l}\text { Disa } \\
\text { bel } \\
\text { Netr } \\
\text { a }\end{array}$ & $\begin{array}{l}\text { Keingin } \\
\text { an } \\
\text { orang } \\
\text { tua } \\
\text { (ayah) } \\
\text { yang } \\
\text { tidak } \\
\text { ingin } \\
\text { anakny } \\
\text { a } \\
\text { mengal } \\
\text { ami } \\
\text { kegagal } \\
\text { an } \\
\text { dalam } \\
\text { hidup }\end{array}$ & $\begin{array}{l}\text { Maha } \\
\text { siswa } \\
\text { Difab } \\
\text { el } \\
\text { bener } \\
- \\
\text { bener } \\
\text { dibant } \\
\text { u } \\
\text { karen } \\
\text { a } \\
\text { secar } \\
\text { a } \\
\text { umum } \\
\text { merek } \\
\text { a } \\
\text { memil } \\
\text { iki } \\
\text { kema } \\
\text { mpua } \\
\mathrm{n} \\
\text { yang } \\
\text { berbe } \\
\text { da- } \\
\text { beda }\end{array}$ \\
\hline 9 & $\begin{array}{l}\text { W } \\
\text { (Se } \\
\text { mest } \\
\text { er 9) }\end{array}$ & $\begin{array}{l}\text { Disa } \\
\text { bel } \\
\text { Run } \\
\text { gu }\end{array}$ & $\begin{array}{l}\text { Karena } \\
\text { tertarik } \\
\text { pada } \\
\text { saat } \\
\text { sekolah } \\
\text { di SLB } \\
\text { diunda } \\
\text { ng } \\
\text { berkunj } \\
\text { ung di } \\
\text { UIN } \\
\text { untuk } \\
\text { mengik } \\
\text { uti } \\
\text { acara }\end{array}$ & $\begin{array}{l}\text { UIN } \\
\text { masih } \\
\text { harus } \\
\text { melak } \\
\text { ukan } \\
\text { prose } \\
\mathrm{s} \\
\text { perbai } \\
\text { kan- } \\
\text { perbai } \\
\text { kan } \\
\text { karen } \\
\text { a } \\
\text { masih } \\
\text { banya } \\
\mathrm{k} \\
\text { kekur } \\
\text { angan }\end{array}$ \\
\hline 10 & $\begin{array}{l}\text { A } \\
\text { (Se } \\
\text { mest } \\
\text { er 9) }\end{array}$ & $\begin{array}{l}\text { Disa } \\
\text { bel } \\
\text { Run } \\
\text { gu }\end{array}$ & $\begin{array}{l}\text { Adanya } \\
\text { prinsip: } \\
\text { aku } \\
\text { bisa, } \\
\text { kamu } \\
\text { bisa } \\
\text { dan kita } \\
\text { bisa }\end{array}$ & $\begin{array}{l}\text { Kuliah } \\
\text { menc } \\
\text { apai } \\
\text { cita- } \\
\text { cita } \\
\text { untuk } \\
\text { teman } \\
\text { - }\end{array}$ \\
\hline
\end{tabular}

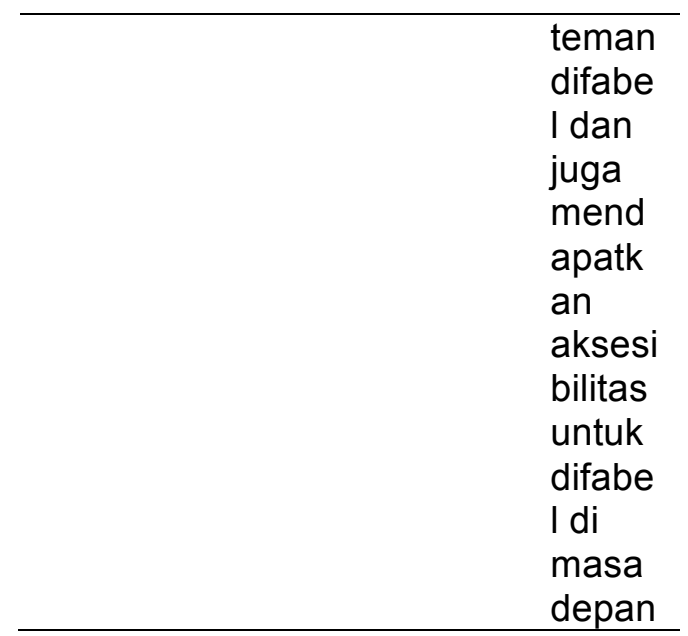

Sumber : Analisis data primer dan informasi Aji dan Erin Feriani, 2017

\section{Hasil dan Pembahasan}

Mahasiswa difabel di UIN Sunan Kalijaga memiliki berbagai latar belakang. Sebagian orang asli Yogyakarta yang bertempat tinggal tidak jauh dari kampus UIN Sunan Kalijaga. Namun sebagian lagi merupakan mahasiswa luar kota seperti Jakarta, Bogor dan luar kota di Jawa. Beberapa mahasiswa difabel memang harus mendapatkan pendamping dan beberapa lainnya hanya membutuhkan kepekaan dari teman-temannya untuk mempermudah mengikuti proses belajar mengajar di kelas. Mengerjakan tugas dari dosen atau bahkan memahami ulang apa yang telah dijelaskan oleh dosen. Tergantung kebutuhan yang disesuaikan dengan difabilitasnya.

Mahasiswa berinisial $B$ yang memiliki difabilitas .tunarungu dan 
tunawicara merupakan salah satu narasumber penulis. Mahasiswa asal Bogor ini menceritakan kehidupannya saat menjadi mahasiswa di salah satu prodi UIN Sunan Kalijaga. Orang tuanya mencarikannya kos-kosan di daerah Sapen karena dalam segi geografis letaknya cukup dekat dengan kampus. Biasanya, ia berangkat kuliah hanya dengan jalan kaki. Awalnya, orang tuanya mendaftarkan B ke UI Depok, mengingat letak kampus UIN lebih dekat dengan rumahnya. Namun karena tidak diterima dan diterima di kampus pilihan ke dua yakni UIN Sunan Kalijaga, maka orang tuanya mengijinkannya untuk menempuh studi di Yogyakarta. Tempat yang jauh dari ke dua orang tuanya. Motivasi dan semangat belajarnya sehingga memberanikan diri untuk pergi ke Yogyakarta ialah karena ia merasa penting untuk ikut serta mengembangkan keilmuannya. Mendapatkan IImu Pengetahuan seperti mahasiswa lain. Selain itu, harapan untuk membahagiakan kedua orang tuanya menjadi faktor penting sehingga memotivasi $B$ untuk menjadi salah satu mahasiswa UIN Sunan kalijaga.

Berbeda dengan $\mathrm{B}, \mathrm{N}$ salah satu Mahasiswa UIN Sunan Kalijaga asal Yogyakarta memang sengaja memilih kampus UIN. Karena menurutnya kampus UIN merupakan salah satu kampus inklusi dan dapat menerima mahasiswa difabel. Mahasiswa penyandang tunarungu dan tunawicara ini pulang pergi ke kampus dengan mengendarai sepeda motor sendiri. Selain itu, mahasiswa asal Yogyakarta lain yang berinisial $A$, setiap harinya ia meninggalkan kursi rodanya di Fakultas. Diantar oleh ibunya menggunakan sepeda motor dan menggendongnya dari depan Fakultas untuk kemudian ibunya juga berperan besar dalam mendukungnya untuk tetap semangat menempuh IImu Pengetahuan.

Hal ini yang menjadi motivasi mahasiswa untuk tetap semangat menjadi mahasiswa dan bagian dari kaum intelektual. UIN Sunan Kalijaga sebagai kampus inkluisif memang memiliki beberapa infrastruktur yang memadai untuk mewadahi mahasiswa difabel. Bahkan dari segi bangunan, seperti Laboratorium Agama dan Difabel Corner merepresentasikan UIN sebagai kampus inklusi. Namun dalam beberapa hal masih ada kesulitan yang dialami oleh mahasiswa difabel. Dalam proses belajar dan mengikuti perkuliahan beberapa mahasiswa difabel masih mengalami beberapa 
kendala. Beberapa kendala antara lain ialah pertama, kesulitan mengakses ruangan di lantai dua dan tiga bagi mahasiswa difabel yang menggunakan kursi roda. Kedua, ketersediaan akses bagi mahasiswa difabel penyandang tunanetra masih minim baik petunjuk arah maupun pendamping. Dalam pembagian kelas, terkadang mahasiswa tunanetra mendapatkan ruang kelas di lantai paling atas. Ketiga, tenaga pendidik atau dosen yang tidak secara khusus memiliki skill untuk berinteraksi dengan mahasiswa difabel. Selama ini UIN Sunan Kalijaga baru menyiapkan infrastruktur. Sumber daya manusia khususnya dosesn belum disiapkan secara maksimal akan tetapi dituntut untuk dapat menghadapi mahasiswa difabel.(PLD UIN Sunan Kalijaga,2016). Padahal akses dan layanan baik infratruktur maupun fasilitas memahami apa yang diajarkan oleh dosen merupakan harapan yang paling besar bagi mahasiswa difabel supaya mereka dapat belajar dengan baik serta memaksimalkan potensi dan skill-nya selama menjadi mahasiswa maupun setelah lulus nanti.

Harapan dari mahasiswa difabel lebih diarahkan pada proses penyelenggaraan pendidikan di UIN
Sunan Kalijaga yang perlu melakukan pembenahan dalam memberikan pelayanan kepada mahasiswa difabel. Harapan tersebut terkait dengan: sarana prasarana (misalnya gedung yang perlu perbaikan untuk bisa diakses mahasiswa difabel, lantai 3), pendamping yang bisa membimbing dalam proses pembelajaran serta dosen yang lebih memiliki pemahaman terhadap mahasiswa difabel.

Dari semua jumlah difabel, beberapa mahasiswa difabel mendapat pendamping khusus terutama saat perkuliahan berlangsung. Pendamping berfungsi untuk menerangkan dan menjelaskan ulang apa yang diajarkan oleh dosen ketika di kelas. Walau begitu, tidak semua difabel mendapatkan pendamping saat proses belajar mengajar di kelas berlangsung. Beberapa mahasiswa bahkan menolak untuk didampingi. Salah satu mahasiswa Prodi Sosiologi FISHUM misalnya, saat proses belajar mengajar berlangsung, ia cukup dibantu oleh teman-teman sekelasnya. Biasanya apabila ada kegiatan di lantai dua atau lantai tiga, teman-temannya ikut membantu mengangkat kursi rodanya naik ke lantai tiga melalui tangga. Mengingat 
belum ada lift yang menunjang akses bagi mahasiswa difabel yang menggunakan kursi roda. Mahasiswa lain seperti penyandang difabel rungu memilih untuk menggunakan hearing aids.

"Fasilitas bagi difabel seperti
saya relatif sama dengan orang
normal. Biasanya hanya
menggunakan alat bantu
dengar. Biasanya kalau lagi
nggak ada pendamping bisa
dibantu oleh teman kelas" (
Wawancara DL, 28 Agustus
2017).

Mendapatkan kesempatan yang sama dalam menimba IImu, mahasiswa Difabel di UIN Sunan Kalijaga juga memiliki banyak prestasi dan karya. Minat bakat tetap dikembangkan melalui berbagai wadah, baik musik, puisi atau bahkan menulis. Mahasiswa Difabel juga seringkali tampil dan bermain musik serta menyanyi di beberapa event yang diselenggarakan oleh mahasiswa maupun birokrasi kampus. Baik seminar, diskusi maupun dialog. Kondisi difabel memang bukan halangan untuk dapat berekspresi sesuai minat dan kemampuan. S merupakan salah satu mahasiawa jurusan Sejarah dan Kebudayaan Islam Fakultas Adab dan ilmu budaya UIN Sunan Kalijaga Yogyakarta adalah salah satu buktinya. Dunia tarik suara digelutinya sejak di bangku SMP. S bergabung dalam sebuah grup band yang terdiri 5 orang, yang seluruh anggotanya merupakan difabel netra. (http//pld.uin-suka.ac.id , Inspirasi "Tetap kuat dalam sedikit Cahaya". diakses tanggal 13 Juni 2017)

Banyak sekali potensi dari teman-teman mahasiswa difabel yang sesungguhnya bisa dikembangkan. Terutama semangat yang sangat tinggi untuk mengembangkan IImu Pengetahuan. Namun, dalam berbagai infrastruktur terutama akses, Fakultas-fakultas di UIN Sunan Kalijaga belum memadai. Misalnya akses untuk mahasiswa yang menggunakan kursi roda untuk menjangkau ruangan-ruangan di lantai 2 dan 3 . Selain itu, penempatan kelas. Bagi difabel netra di beberapa fakultas seringkali mendapatkan kelas di lantai paling atas dan biasanya mereka pergi mencari kelas tanpa pendamping.

Sebagai kampus yang terbuka untuk umum dan meberikan kesempatan yang sama termasuk bagi difabel, ada beberapa hal yang perlu diperbaiki dalam infrastruktur terutama bangunan kampus. Hal ini untuk mengimbangi semangat dan potensi-potensi mahasiswa difabel itu sendiri. Potensi dan semangat yang tinggi dari teman-teman difabel tetap 
harus diwadahi sehingga kampus UIN Sunan Kalijaga menjadi benarbenar kampus yang inklusi. Maka penelitian ini sesungguhnya ingin melihat dan menelisik lebih dalam apa saja motivasi mahasiswa difabel yang masuk ke UIN Sunan Kalijaga. Setelah itu, tulisan ini juga ingin melihat apa saja wadah yang diberikan kampus kepada mahasiswa difabel serta harapan dari temanteman difabel dalam proses belajar mengajar supaya mereka bisa memaksimalkan potensi untuk mengembangkan IImu Pengetahuan dan skill yang dimiliki.

Berdasarkan tabel 1 tentang motivasi dan harapan dari beberapa mahasiswa difabel di UIN Sunan Kalijaga menunjukan bahwa motivasi mahasiswa difabel dalam proses penyelenggaraan pendidikan tinggi tidak bisa dipisahkan dari adanya prinsip pendidikan kritis, bahwa pendidikan untuk semua. Spirit tersebut menyala dalam diri mereka untuk ikut dalam proses pendidikan yang diselenggarakan oleh kampus inklusi, untuk bisa memiliki kesempatan yang sama seperti orang normal. Diantaranya: bisa berkeliling dunia dengan bekal pendidikan yang dimilikinya serta mendapatkan kesuksesan dalam hidsup.

Pendidikan kritis pada dasarnya merupakan aliran, paham dalam pendidikan untuk pemberdayaan dan pembebasan. Pada titik ini, pendidikan berperan dalam proses transformasi sosial terbagi menjadi dua pendapat, yakni : (1) penganut paham reproduksi, sangat pesimis terhadap pendidikan yang berperan untuk perubahan sosial menuju transformasi sosial. Pendidikan dalam sistem kapitalisme berperan untuk mereproduksi sistem itu sendiri; dan (2) penganut paham produksi, pendidikan mampu menhgciptakan ruang untuk tumbuhnya resistensi dan subversi terhadap sistem yang dominan (Mansour, 2001: hlm 28-33). Pendidikan merupakan media untuk resistensi dan aksi sosial yang tidak dapat dipisahkan dan merupakan bagian dalam transformasi sosial.

Motivasi kelompok difabel
dalam proses pendidikan inklusi
mengacu pada pemahaman kritis
yang kedua, bahwa pendidikan
inklusi dapat menumbuhkan
resistensi terhadap sistem pendidikan
yang eksklusif, bahwa pendidikan
diperuntukan bagi kelompok yang
mampu terlibat dalam proses
pembelajaran secara normal.
Faktanya, pada proses pembelajaran
kelompok yang berkebutuhan khusus


ini mampu mengikuti materi yang diberikan di kelas. Tentunya dengan adanya pendamping yang menyertainya , baik dari pendamping yang disediakan oleh PLD UIN Sunan Kalijaga atau pun temanteman sekelas yang memiliki kepedulian terhadap temantemannya yang berkebutuhan khusus. Kemampuan mereka dalam proses pembelajaran dapat dilihat dari jawaban yang diberikan pada saat ujian tengah semester dan ujian akhir semester atau pun pada saat presentasi di kelas menyampaikan makalah.

Proses pendidikan kritis berpijak pada pemikiran dan paradigma kritik ideologi terhadap sistem dan struktur sosial, ekonomi, politik yang tidak adil. Proses pendidikan adalah merupakan proses refleksi dan aksi (praksis) terhadap seluruh tatanan dan relasi sosial dari sistem dan struktur sosial. Hal ini dilandasi tentang tugas utama pendidikan untuk menciptakan ruang agar sikap kritis terhadap sistem dan struktur yang diskriminatif terhadap kelompok yang memiliki kebutuhan khusus menjadi terbongkar dan lebih terbuka. Amanat ini tersirat dalam wacana pendidikan inklusi yang terbuka kesempatan bagi mahasiswa difabel.
Ruang kritis yang dimaksud yaitu tersedianya lembaga pendidikan yang bersifat inklusi sebagai salah satu bagian refleksi dan aksi terhadap lembaga pendidikan dominan yang eksklusif. Hal yang paling nampak adalah adanya kampus inklusi, yang jumlahnya relative lebih sedikit dibandingkan dengan kampus eksklusif. Hal ini membuktikan bahwa upaya untuk mewujudkan sistem atau tatanan anti mainstream tidak lah mudah. UIN Sunan Kalijaga memberikan kesempatan bagi mahasiswa difabel merupakan proses panjang untuk bisa diterima semua stakeholder. Membutuhkan waktu lama terkait dengan sistem, struktur dan norma yang berlaku di lingkungan pendidikan masih bersifat eksklusif. Mengubah paradigma eksklusif menjadi inklusi diperlukan sumberdaya dosen, tenaga pendidikan dan pejabat struktural untuk memiliki pandangan yang sama dalam memberikan pelayanan kepada mahasiswa difabel.

Pendidikan kritis sangat memerlukan perspektif kelas dalam kegiatan analisis proses pendidikan, karena analisis kelas memberi perangkat dalam rangka memahami sistem ketidakadilan sosial. Hampir semua golongan masyarakat menjadi 
korban dari sistem ketidakadilan kelas, namun karena yang menjadi korban ketidakadilan kelas adalah masyarakat bawah, maka seolaholah analisis kelas hanya menjadi alat perjuangan golongan miskin. Dengan adanya analisis kelas dapat memahami dam membongkar sistem ketidakadilan secara luas. Tanpa analisis kelas, perubahan sosial menjadi reduksionisme, dimana lebih memusatkan perhatian pada manusianya saja.

Analisis kelas dalam proses pendidikan inklusi memfokuskan pada relasi struktur sosial ketimbang hanya memfokuskan pada korban eksploitasi. Sehingga agenda utamanya tidak hanya sekedar menjawab kebutuhan praktis untuk merubah kondisi golongan yang berbeda, melainkan juga menjawab kebutuhan strategi golongan yang berbeda tersebut, yakni memperjuangkan perubahan posisi golongan berbeda, termasuk konter hegemoni dan konter wacana terhadap ideologi sosial yang mengakar pada keyakinan.

Stratifikasi social mengacu pada pembedaan masyarakat secara berdasarkan kelas-kelas tertentu secara hierarkhis (bertingkat). Perwujudannya adalah kelas yang rendah-tinggi dan tidak setara dalam segala macam aspek. Diantaranya: pembagian hak dan kewajiban, kewajiban dan tanggung jawab nilainilai social dan pengaruhnya dalam masyarakat. Bentuk-bentuk konkrit stratifikasi social sangat beraneka ragam, yang dapat diklasfikasikan menjadi 3, yaitu: ekonomi, politik dan jabatan-jabatan tertentu dalam masyarakat. Ketiganya berhubungan erat dan saling mempengaruhi sesuai dengan system nilai yang berkembang dalam masyarakat itu sendiri (Soekanto,2001: hlm 253)

Konsep kelas tersebut dapat digunakan untuk membaca tentang difable dari perspektif stratifikasi social. Pembanding kelasnya tentu saja individu atau masyarakat yang tidak memiliki kondisi fisik yang tidak berbeda (normal). Mahasiswa difable ditinjau dari fisik memiliki berbagai macam keterbatsan untuk melakukan berbagai macam aktivitas yang bernilai ekonomi dan mendapatkan pengaruh secara politis dalam masyarakat. Topangan ekonomi lebih dibebankan kepada anggota keluarga yang lain atau pun kepada masyarakat normal. Ketergantungan ekonomi kepada pihak lain ini secara otomatis menyebabkan mereka menduduki kelas yang lebih rendah. Atau bisa dikatakan difable sebagai salah satu kelompok yang 
termarginalkan karena kelemahan fisiknya yang mempengaruhi peran dalam bidang ekonomi, social dan politik. Pada situasi kelas yang termarginalkan tersebut, keberadaan pendidikan kritis benar-benar sebagai sebuah konter wacana dan hegemoni untuk pendidikan tinggi mainstream tidak bisa dihindarkan atau sebuah keniscayaan.

Penyelenggaraan pendidikan inklusi di UIN Sunan Kalijaga memberikan harapan-harapan baru bagi kelompok difabel. Harapan tersebut mekar dan bersemi karena selama ini, sebagai salah satu kelompok marginal kesempatan mereka untuk mendapatkan hak pendidikan dari tingkat dasar sampai dengan pendidikan tinggi teramatlah langka diberikan fasilitas oleh Negara. Kalaupun ada kesempatan, mereka harus membayar dengan harga yang relative tinggi untuk berbagai macam fasilitas. Adanya pendidikan inklusi tidak mengherankan memunculkan harapan dan semangat di kalangan mahasiswa difabel. Beberapa harapan mereka tentang penyelenggaraan pendidikan inklusi di UIN adalah sebagai berikut:

1. Perbaiki Insfrastruktur, ingin ada pendamping saat perkuliahan berlangsung dan ingin memperdalam bahasa Arab.

2. Ingin ada pendamping saat perkuliahan untuk mempermudah memahami apa yang dijelaskan oleh dosen.

3. Difasilitasi pendamping saat perkuliahan

4. Bisa mengakses semua ruangan termasuk lantai tiga

5. Difasilitasi pendamping saat perkuliahan. Apabila tidak ada pendamping, harapannya bisa dibantu oleh teman kelas.

6. Kuliah lancar, ilmu agama bertambah, mendapatkan pengetahuan secara integrasi dan interkoneksi sebagai bekal untuk menjelajah dunia

7. Bisa dapat kuliah di tempat yang memiliki akses bagi difabel

8. Mahasiswa Difabel benerbener dibantu karena secara umum mereka memiliki kemampuan yang berbedabeda

9. UIN masih harus melakukan proses perbaikan-perbaikan karena masih banyak kekurangan

10. Kuliah mencapai cita-cita untuk teman-teman difabel dan juga mendapatkan aksesibilitas untuk difabel di masa depan. (Analisa Data Primer, 2017)

Berdasarkan harapan dari informan tersebut dapat diklasifikasikan menjadi 3 hal, yaitu: perbaikan sarana dan prasarana yang lebih menunjang pendidikan inklusi, memberikan pendamping bagi mahasiswa difable sehingga mereka bisa memahami materi yang disampaikan oleh dosen serta perlu 
adanya peningkatan kompetensi dosen untuk bisa memberikan materi yang efektif dan efisien kepada mahasiswa difable.

Harapan-harapan mahasiswa difable tersebut tidak bisa dipisahkan dari motivasinya dalam menggapai impian yang dicita-citakan. Motivasi yang tinggi menghasilkan harapan yang tinggi pula, terutama terhadap proses pembelajaran di pendidikan tinggi. Harapan mereka yang menginginkan perbaikan sarana prasarana berarti sarana yang diperuntukan bagi mahasiswa difable selama ini, belum bisa memenuhi kebutuhannya. Harapan mereka untuk diberi pendamping untuk memahami proses belajar mengajar dalam setiap perkuliahan menunjukan bahwa kualitas dan kuantitas relawan pendamping yang selama ini ada belum mencukupi kebutuhan mahasiswa difable dalam setiap perkuliahan yang diikuti oleh mereka. Idealnya dalam setiap satu mata kuliah ada mahasiswa pendamping satu, sehingga mereka benar-benar memahami materi yang disampaikan oleh dosen. Harapan adanya dosen yang bisa kooperatif dalam menyampaikan materi kepada difable menunjukan bahwa mayoritas dosen-dosen di lingkungan UIN Sunan Kalijaga belum memiliki kemampuan, kesabaran dan kompetensi untuk mengajar kepada mahasiswa difable.

Tentunya harapan-harapan dari mahasiswa difable tersebut menunjukan sisi kekurangan dari penyelenggaraan pendidikan inklusi di lingkungan UIN Sunan Kalijaga yang penyelenggaraannya relative baru dibandingkan dengan pendidiakn eksklusif. Harapanharapan itu merupakan keinginan adanya perbaikan pelayanan pada masa-masa yang akan datang. Penyelenggaraan pendidikan inklusi menurut konsep Sosiologi merupakan salah satu bentuk konsep keseimbangan yang mengacu pada sistem tindakan Parson (1951) yang dikenal dengan AGIL yaitu: A (Adaptation), G (Goal Attainment), I (Integrasi) dan L (latensi). Adaptasi yang dimaksud adalah sebuah sistem harus mampu menanggulangi situasi eksternal yang gawat, menyesuaikan diri dengan lingkungan dan menyesuaikan lingkungan untuk kebutuhannya. Goal Attainment berarti sebuah sistem harus mendefinisikan dan mencapai tujuan utamanya. Integrasi berarti sebuah sistem harus mengatur antar hubungan bagianbagian yang menjadi komponennya serta mengelola antar hubungan 
ketiga fungsi yang lainnya. Latensi berarti sebuah sistem harus melengkapi, memelihara dan memperbaiki, baik motivasi individual atau pun pola-pola kultural yang menciptakan dan menopang motivasi. Keempat hal tersebut digambarkan dalam struktur sistem tindakan yang saling melengkapi satu sama lain dalam keseimbangan sistem sosial.

Tabel 2: Struktur Sistem Tindakan Umum

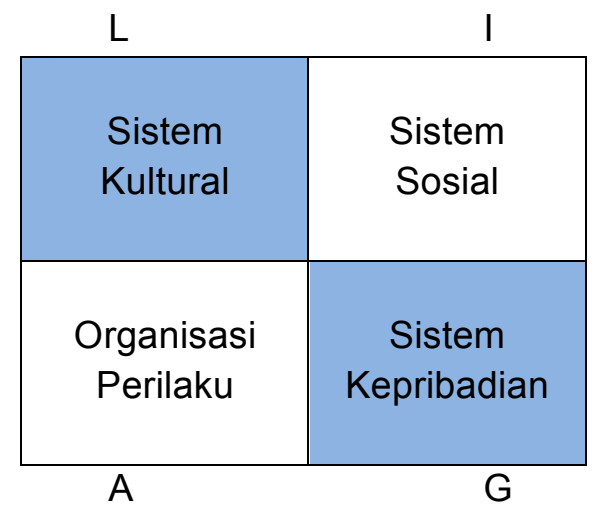

Sumber : Ritzer, 1995

Berdasarkan tabel 2 tersebut menunjukan bahwa keempat struktur sistem tindakan umum tersebut saling berinteraksi menuju keteraturan social. Keseimbangan sistem akan terganggu, apabila salah satu unsur dalam sistem, misalnya sistem kultural tidak menjalankan fungsinya dengan baik. Artinya dalam masyarakat akan timbul crowded atau pun konflk yang berkepanjangan sebagai akibat salah satu sub system tidak berfungsi dengan sebaikbaiknya dan sebagaimana mestinya.

Dalam struktur system tindakan umum, pendidikan merupakan salah satu bentuk dari system kultural, yang berfungsi untuk melaksanakan fungsi pemeliharaan pola dengan menyediakan pola dengan menyediakan actor seperangkat norma dan nilai yang memotivasi mereka untuk bertindak (Ritzer, 1995). Pemeliharaan pola tentunya mengacu pada keseimbangan system social sebagai tujuan dari perspektif structural fungsional ini. Pendidikan diharapkan mampu menyembangkan masyarakat dengan terjaganya moralitas, nilai dan norma dalam masyarakat sehingga keamanan system menjadi terkendali dan masyarakat memiliki kompetensi untuk menyelesaikan berbagai macam permasalahan yang mereka hadapi sendiri.

Adanya pendidikan inklusi yang dijalankan pada Perguruan Tinggi sebagai salah satu bentuk pendidikan kritis bagi mahasiswa difabel merupakan penyangga keseimbangan system social. Pendidikan inklusi menghapus kesenjangan hak pendidikan untuk semua. Semua warga Negara berhak mendapatkan pengetahuan melalui pendidikan formal yang 
diselenggarakan oleh Negara.

Dengan demikian, system kultural sebagai salah satu sub system dalam structural fungsional dapat menjalankan fungsinya secara optimal. Semua lapisan masyarakat dapat menikmati fasilitas pendidikan yang diberikan oleh Negara. Selain itu, di lingkup intern juga tidak terjadi konflik social sebagai akibat penyelenggaraan pendidikan yang senjang serta masyarakat memililki pengetahuan dalam menempatkan diri sebagai bagian dari masyarakat dalam skala yang luas. Sistem social menjadi aman dan terkendali.

Pada tataran keseimbangan system, pendidikan inklusi yang diselenggarakan oleh UIN Sunan Kalijaga sudah mampu meneyelenggarakan fungsinya dengan bai untuk keseimbangan system, terutama berkaitan dengan hak-hak seluruh warga Negara dalam mendapatkan pendidikan tanpa memandang perbedaan kelas dan keterbatasan fisik. Penyelenggaraan yang masih dalam hitungan dibawah satu dasa warsa ini masih memiliki keterbatasan memberikan pelayanan secara optimal kepada kelompok difabel itu sendiri. Terutama dalam pemberian fasilitas yang masih jauh dari kelayakan, pendamping yang masih kurang jumlah dan kualitasnya serta sumber daya dosen yang perlu ditingkatkan untuk memberikan pendidikan inklusi kepada mahasiswa difabel.

\section{Simpulan}

Pendidikan inklusi menjadi tujuan penyelenggaraan pendidikan di UIN Sunan Kalijaga merupakan fungsi ideal pada sistem kultural dalam perspektif structural fungsional. Dengan terselenggaranya pendidikan inklusi tersebut memberikan peluang bagi mahasiswa difabel yang memiliki keterbatasan fisik untuk mendapatkan pendidikan yang sama dengan mahasiswa normal. Ketika mahasiswa difabel mendapatkan kesempatan yang sama berarti masyarakat secara utuh mendapatkan pendidikan dan system dapat berjalan dengan baik.

Peluang tersebut ditangkap oleh mahasiswa difabel untuk mendapatkan pendidikan yang sama dengan kelompok lain. Motivasi mereka yang tinggi untuk mendapatkan pengetahuan dan tingkat pendidikan yang sama dengan mahasiswa normal merupakan salah satu indikasi utama bahwa mahasiswa difabel sebenarnya juga memiliki keinginan untuk maju, memiliki kesempatan yang sama dengan mahasiswa lain 
dan terbebas dari ketergantungan kepada anggota keluarga atau masyarakat lain dengan berdiri di kaki sendiri. Terdidiknya mahasiswa difabel akan terjaga keseimbangan system karena mereka menjadi bagian system social-ekonomi-politik dan keamanan yang memiliki kemampuan yang sama dengan masyarakat yang lain. Perspektif, pengetahuan dan kemampuan bisa berdiri di kaki sendiri ini akan menguatkan system kultural dalam perspektif structural fungsional.

Hambatan yang muncul dari system penyelenggaraan pendidikan inklusi di lingkungan UIN Sunan Kalijaga ini, masih bersifat komprehensif. Hal ini mengingat dari adanya motivasi untuk mendapatkan pendidikan yang sama dengan mahasiswa lain di kampus inklusi belum bisa terselenggara dengan sebaik-baiknya untuk saat ini, sehingga muncul berbagai macam harapana untuk perbaikan pendidikan inklusi itu sendiri di masa yang akan datang. Tiga hal harapan yang menjadikan tantangan bagi UIN dalam menyelenggarakan kampus inklusi ini menyangkut: (1) kualitas mahasiswa difabel itu sendiri dalam menerima materi perkuliahan, artinya proses seleksi perlu dilakukan untuk mendapatkan kualitas mahasiswa yang bermutu dan memiliki kompetensi tinggi; (2) sarana dan prasarana yang perlu ditingkatkan dalam memberikan pelayanan yang optimal bagi mahasiswa difabel, mulai dari sarana prasarana gedung, kursi, jalan, meja-kursi yang digunakan untuk pembelajaran, toilet, buku-buku, sarana pembelajaran yang terkini, misalnya e learning; (3) kualiatas relawan sangat perlu ditingkatkan dari segi jumlah dan kompetensinya dalam memberikan pelayanan terhadap mahasiswa difabel. Harapannya, proses menjadi relawan difabel ini bisa mereka praktikan dalam ruang dan waktu yang lebih luas di luar kampus; (4) kualitas dosen perlu dibekali dengan komptensi dalam memberikan pembelajaran kepada mahasiswa inklusi yang memerlukan keterampilan khusus dibandingkan dengan mengajar kepada mahasiswa biasa dan (5) keseluruhan system yang terlibat dalam proses pembelajaran, mahasiswa secara keseluruhan dan tenaga pendidikan harus menyadari kalau berada di kampus inklusi sehingga semua stakeholder terbiasa memberikan pelayanan kepada mahasiswa inklusi. Sebagai contoh, dalam proses pembelajaran mahasiswa akan terbiasa mendengarkan dengan 
sabra, apabila ada mahasiswa difabel mengungkapkan pendapatnya.

Demikian halnya dengan tenaga kependidikan akan selalu sabra dalam memberikan pelayanan administrasi kepada mahasiswa difabel. Dengan demikian menuju kampus inklusi adalah tanggung jawab semua pihak penyelenggara di kampus UIN Sunan Kalijaga,

\section{Ucapan Terima Kasih}

Terimakasih disampaikan

kepada semua pihak yang terlibat dalam penelitian ini sehingga terlaksana dengan baik dan tim redaksi Jurnal Pendidikan Sosiologi Fakultas IImu Sosial UNY yang telah mempublikasikan penelitian ini

\section{Daftar Pustaka}

Abdullah Fikri, Partisipasi Masyarakat Difabel dalam Pembentukan Kebijakan Pendidikan Tinggi, 2014, INKLUSI, Vol.1 No.1, januari-juni 2014.

Faqih, Mansour, Pendidikan Popular, Membangun Kesadaran Kritis. Yogyakarta: Insist, 2000

Feriani, Erin, Interaksi Sosial dosen terhadap mahasiswa difable di Perguruan Tinggi Inklusif UIN Sunan Kalijaga Yogyakarta", Yogyakarta: UIN Sunan Kalijaga, 2017.

Ilahi, M.Takdir, Pendidikan Inklusif: Konsep dan Aplikasi, Yogyakarta: ARRUZZ MEDIA, 2013

Jamil Suprihatiningrum, Persepsi Siswa Difabel terhadap Praktik Pendidikan Inklusif di SMA
Inklusi di Yogyakarta, 2016, INKLUSI, Vol.3, No.2, 2016. Kristiyanti, Emilia, Pendidikan Inklusi:Harapan bagi Anak-anak Berkebutuhan Khusus, JP 65, Jakarta

Praptiningrum N., Fenomena Penyelenggaraan Pendidikan Inklusif bagi Anak Berkebutuhan Khusus, Jurnal Pendidikan Khusus, Vol 7 No.2, 2010

Soekanto, Soerjono, Sosiologi Suatu Pengantar, Jakarta: Rajawali Pers, 2001

Yulianto, M. Joni, Konsepsi Difabilitas dan Pendidikan Inklusi, INKLUSI, Vol 1, No.1, JanuariJuni 2014

-------- Sukses belajar di Perguruan Tinggi, Profil UIN Sunan Kalijaga, 2015.

Data Pusat Layanan Difable (PLD) UIN Sunan Kalijaga Yogyakarta, 2016.

http//pld.uin-suka.ac.id, Inspirasi "Tetap kuat dalam sedikit Cahaya". diakses tanggal 13 Juni 2017. 